\title{
The coastal fortification of Cape de Forma (Menorca, Spain): petrophysical characterization and alteration of stones and ancient mortars
}

\author{
Anna Depalmas ${ }^{\mathrm{a}}$, Stefano Columbu ${ }^{\mathrm{b}}$ \\ ${ }^{a}$ Dipartimento di Storia, Scienze dell'Uomo e della Formazione, Università di Sassari, Sassari, Italia, \\ depalmas@uniss.it, 'Dipartimento di Scienze Chimiche e Geologiche, Università degli Studi di Cagliari, Cagliari, \\ Italy, columbus@unica.it
}

\begin{abstract}
The site of Cap de Forma is frequently mentioned in the cartography of the 18th and 19th centuries, particularly the tower of Es Canutells.

The archaeological site of Cap de Forma is on a coastal cape, and consists of a main cyclopean monument, which closes off an isthmus, a necropolis of rock-cut tombs (cuevas) dug out the cliff overlooking the sea and a second, very degraded, more central area. The promontory rises above the sea, with cliffs of more than $30 \mathrm{~m}$ in height.

On the isthmus, the large elongated rectangular cyclopean construction protects the entrance from the interior. It is not a Talayot, at least not in the common sense of the term, as the building is different from the known types of this class of monument.

The external wall is roughly built. It consists of local limestone slabs, mainly placed horizontally but with some vertical ones juxtaposed among them. Once one passes this wall, through an opening near the edge of the cliff, one can access the south of the structure.

Here the slow collapse of the monument and its use as a modern military lookout post have combined to give the walls an untidy appearance. It consists of massive parallel walls arranged roughly in large steps, alternating with piles of small stones.

Some walls were probably destroyed by the troops stationed in the adjacent fortified manor house in the 18 th century AD, were also detected in this space.

In a open space, between two living areas (central and eastern spaces), a large cylindrical hollow carved into the limestone was found in a depression filled with small stones. This may well have been a cistern for collecting rainwater for the resident community.
\end{abstract}

Keywords: Fortification, Coast, Menorca, Reuse, Physical properties, Petrograhic features, Decay

\section{Introduction}

Cap de Forma is an archaeological complex of particular importance. It is coastal and fortified, as are few other sites on Menorca. Moreover, its strategic position, which overlooks and provides vistas of all the south coast of Menorca, is of particular relevance to the study of navigation and routes to and from the islands (Fig. 1).
The project Cap de Forma (Menorca): The Navigation in the Western Mediterranean from the Bronze Age to the Iron Age started in 1990's, sponsored by the University of Cagliari (G. Tore, C. Del Vais) and Sassari (G. Tanda, A. Depalmas) and the Museu de Menorca (L1. Plantalamor Massanet). 
Main objective of research was to detect the coastal fortification (Fig. 2) and the hypogeal necropolis (Fig. 3) of Cap de Forma (Mahon, Menorca).

The research initially had the aim of investigating in depth the cyclopean monument, in order to determine the period of construction and the culture to which it belonged.

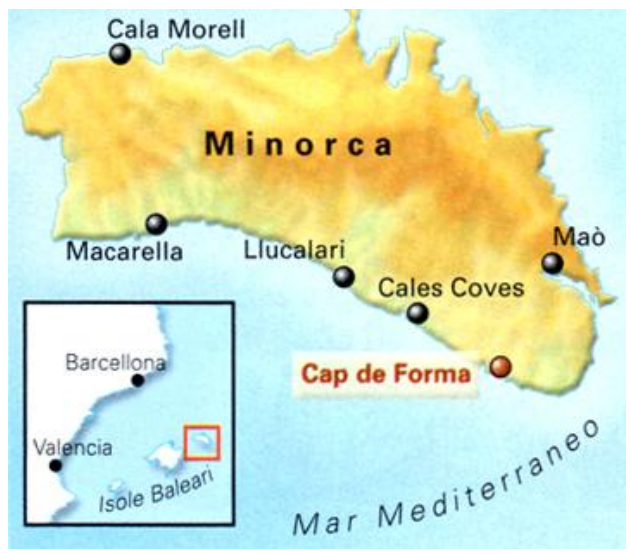

Fig. 1- Location of Cap de Forma (Mahon) on the island of Menorca

Currently the investigation are in progress and addressed to the study of materials used in the fortifications carried out in the area adjacent to Cap de Forma's main monument. The aim of this paper is to provide some indications about the preliminary results of archaeological investigations of masonry remains and methodological approach on the petrographic and physical characterization of stones and mortars.

\subsection{History of the research}

The site of Cap de Forma is frequently mentioned in the cartography of the eighteenth and nineteenth centuries, with particular reference to the tower of Es Canutells.

In the description of the south coast of Menorca written by the Archduke Luis Salvador of Austria (Die balearen in wort bild) dating from the nineteenth century are quoted the archeological ruins on the Cape, with the description of the rock-cut tombs (cuevas) (Fig. 2 ), the mention of the presence a cairn on like a talaiot and the observation that from the headland is possible to see the island of Cabrera.

The research in Cap de Forma started in 1991 and the first excavation field took place in 1997 (Plantalamor Massanet et al., 1999).

This intervention interested the outside (in the north) and the inside area (in the south) of the structure in cyclopean technique and the excavation in the necropolis of the Cuevas 3 and 22 (Figs. 2, 3).

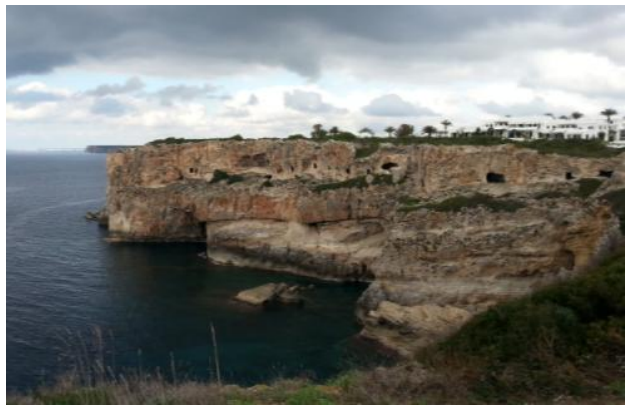

Fig. 2- View of the necropolis into the cliff

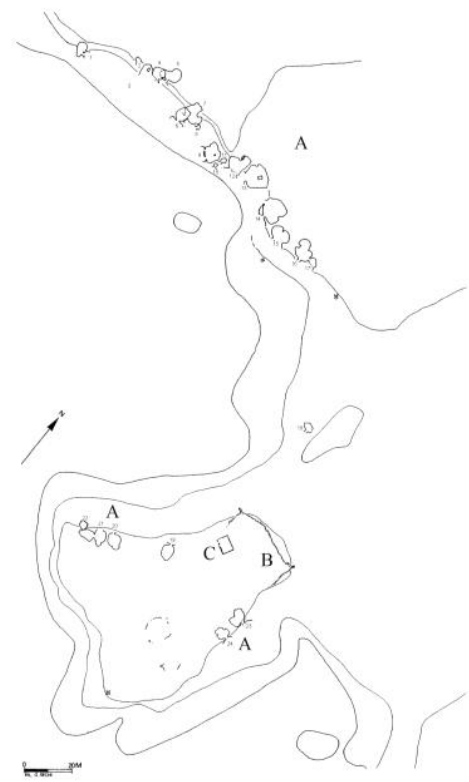

Fig. 3- Map with the necropolis (A), the monument in cyclopean technique (B) and the fort/lookout (C).

From this time, many field works (1998-2003, 2009-2014) took place, and the excavations are focused on the monument in cyclopean 
technique with advancing of the excavation in the south area of it.

\section{The archaeological complex}

Cap de Forma, also known by the name of Es Caparrot de Forma or Es Castellàs de Forma, is located in the south-east coast of the Menorca island, near the village of Sant Climent, around the administrative boundaries of Maó.

It occupies a rocky promontory out into the sea with the sides cut into cliff (Fig. 2); then due west, a short distance away is the bay of
Canutells, and not far to the east are the bays of Binidalí and Biniparratx.

The archaeological site of Cap de Forma, as already said, is on a coastal cape, and consists of a main monument in cyclopean technique that closes an isthmus (Figs. 2, 3), a necropolis of rock-cut tombs (cuevas) digged on the cliff overlooking the sea and a second more inside, very degraded.

The promontory, which rises on the sea with cliffs that exceed $30 \mathrm{~m}$ in height, has low vegetation of juniper and lentisk that conceals dry stone structures hardly visible.

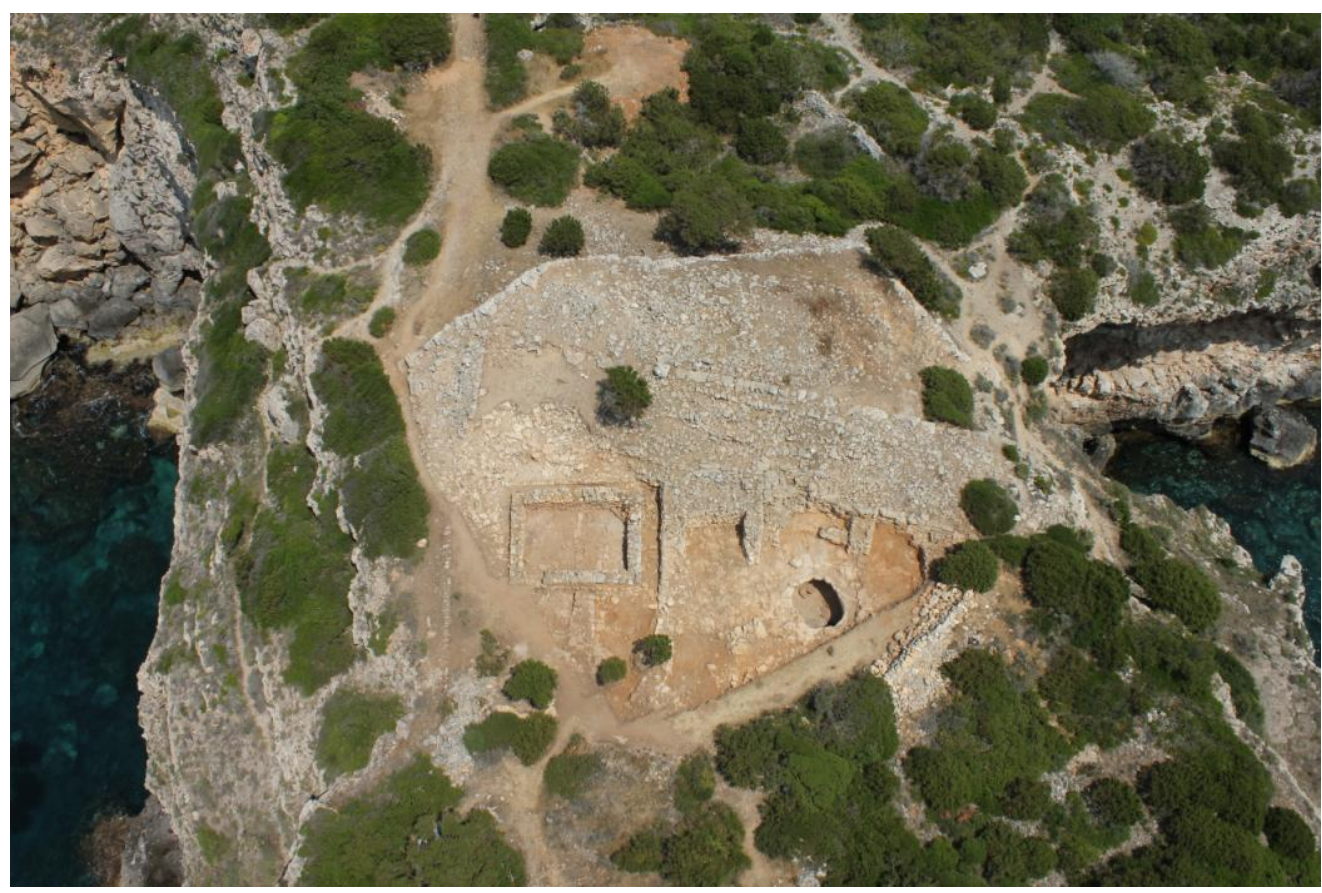

Fig. 4- Aerial view of the main monument, and of the excavated area. Here are clearly visible, on the left, the rectangular plan of the lookout and, on the right, the rounded perimeter of the cistern, by G. Taboad

\subsection{The monument in cyclopean technique}

In the area of the isthmus, the big construction in cyclopean technique and rectangular elongate plan protects the entrance from inland (Fig. 1).

It is not a Talaiot, at least in the common sense of the term, as the building is different from the known types within this class monumental.
For those arriving from inland -i.e. from the north- the monument appears as a massive scarp wall strongly inclined (the maximum height remaining is $4 \mathrm{~m}$ ), developed in length until to block any possibility of access to the promontory (33 $\mathrm{m}$ approximately in length).

The technique of external wall is characterized by long slabs in local limestone. 
The removal of the deposit allowed to highlight the presence of some segments of walls parallel and orthogonal to the external surface wall of the main structure, identified as some living spaces leaning against the monument (Fig. 4). These are:

- to the west, a space of elongated rectangular plan, not completely identifiable because in part covered by the fortified house;

- a central space, of quadrangular plan, (about 6 $m \times 4$ ), difficult to define as regards the southern side;

- in the most eastern part, a space presumably open-air with an area of combustion installed close the monument, in front of a large tank for rain water.

\subsection{The fort/lookout}

From the beginning of the research (1991), after the first cleaning operation appeared a structure of recent times compared to the prehistoric complex.

This fortified house (Fig. 5) was built at the SW corner of the cyclopean monument, using stones removed from the ancient structure.

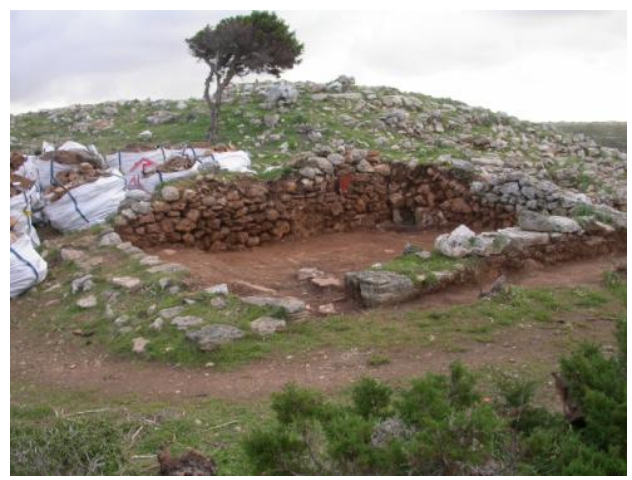

Fig. 5- The fort-house during the excavation

The plan is rectangular, regular, with the door opened near the southwest corner of the south long side; though no longer visible, in the middle of the opposite long side, it had to be a window. Inside the fort, it has brought to light a fireplace located in the northeast corner of the room with still inside layers of ash (Fig. 6).

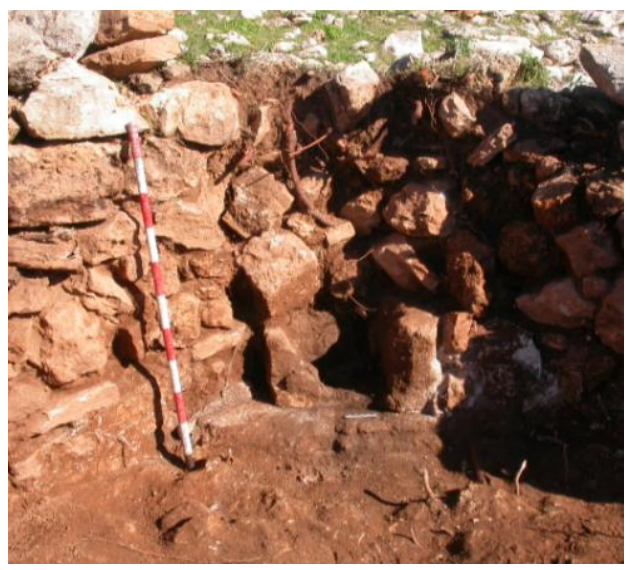

Fig. 6- The fireplace into the corner of the fort

Near were found materials related to the first phase of use of the building, such as ceramic, coins, pendants and pipes.

The identification of parts of plaster covered walls coincided with the discovery of a level of collapsed roof rich in tiles, flakes of plaster and artifacts related to the upper parts of the building (nails).

The inner floor was characterized by a layer of very rough and damaged well-trod soil (Fig. 7).

Below the plane of use, has been identified an earlier wall incorporated into the foundation, which continues on the outside, to the south.

The continuation of the investigation into the fort has therefore determined not only its use over time, but also the presence of a more ancient structure below, on which it was set construction.

The most common materials consist of buttons, coins, manufacturing mainland (Valencia?) ceramics decorated with blue enamel and pipe in meerschaum.

Based on documentary sources and the findings, the fort/lookout is to be referred to the seventeenth century.

In the upper part of the main cyclopic monument, in 2001, was identified a cavity, delimited by a wall, where inside there were a soil (US 20) containing large lumps of lime. This stratigraphic unit is largely made up of lime 
powder, and the wall of the cavity, seems made for the purpose of the production of lime by burning the available limestone material.

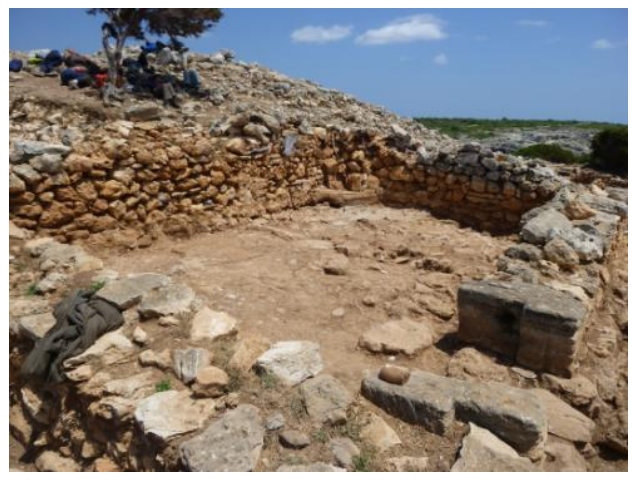

Fig. 7- The inner well-trod soil

Thus, in the seventeenth century AD, the troops exploited intensely the strategic potential of the site, from which it's possible see, over most of the southern coast of the island, Mallorca and, according to sources, even the island of Cabrera.

For the space of the central dwelling was also possible to detect the trace of the south wall, probably destroyed by the troops stationed in the adjacent fortified manor house in the eighteenth century AD.

\subsection{The cistern}

Between the two above mentioned living areas (central and eastern spaces), in a depression filled with little stone, has been identified a large cylindrical hollow carved into the limestone, which can be interpreted as a cistern for collecting rainwater for the community (Fig. 8).

The cistern (approximately $3 \times 3 \mathrm{~m}$ ) was found full of filling. The removal of the deposit of stones and soil has clarified the function of the cistern and its time in use until fairly recently, that seem to coincide with the final phases of life of the fort. The bottom of the deposit seems to have been sealed with several layers of mortar.

The presence of some cracks in the rock suggests that this mortar has been taken to seal the cracks so that the tightness of the deposit was not compromised.
The radiocarbon dating conducted by the Royal Institute for the Study and Conservation of Belgium's Artistic Heritage of Brussels on frustules of coal inside the mortar showed the first century A.C. / I sec. D.C. and the third and fourth century D.C. as the times in which these interventions were operated.

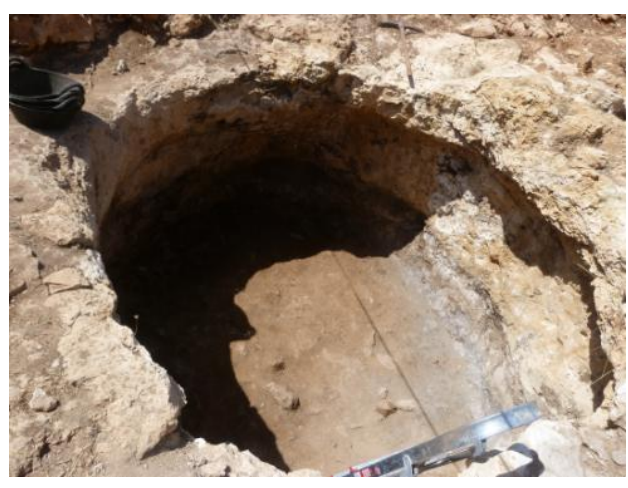

Fig. 8- The cistern for collecting rainwater

\section{Materials and methodological approaches}

\subsection{Petrophysical characterization}

\subsubsection{Operative activities}

The survey investigations done on the masonry of fortifications are set according to the diagram below (Fig. 9, from Columbu \& Verdiani 2011), according to following operative phases:

- Study of the existing bibliography and of unpublished archival sources;

- Architectural reading and analysis of the structural aspects (planimetric distribution, building systems, articulation of the wall textures, etc.);

- Macroscopic mapping of characteristics of geomaterials and various forms of alteration (dechoesion, alveolation, exfoliation, etc.) according to Recommendations Nor.Ma.L. 1/88 (1988) and other criteria (Coroneo \& Columbu, 2010; Macciotta et al., 2001);

- Sampling stones and mortars from monument and rock outcrops (according to Recommendations Nor.Ma.L. 3/80, 1980) as a function of the representativeness of the various lithotypes and kind of mortars; 
- Petrographic analysis by polarized microscopy of lithologies and mortars for define the mineralogic composition and micro-structure and textures;

- Physical analysis of geomaterials (solid, real and bulk densities, porosity, water absorption, hydric dilatation, etc.) according to Columbu et al. 2014, 2015 (in press) and UNI EN 1936, UNI EN 13755;

- Mechanical tests by Point Load Test for define the resistance of materials expressed as punching strength and for define indirectly the hydraulic degree of mortars (also according to Moropoulou et al., 2003);
- Thermo-gravimetric and thermal-differential analysis of mortar binder for define some compositional characteristics;

- Analysis of alteration processes and mechanism of physical and chemical decay of materials present into the monument.

\subsubsection{Analytical methods}

Petrographic determinations of mineralogical composition were carried out on polished thin sections by optical polarised microscopy.

To the limestones were used the Folk classifications $(1959,1965)$.

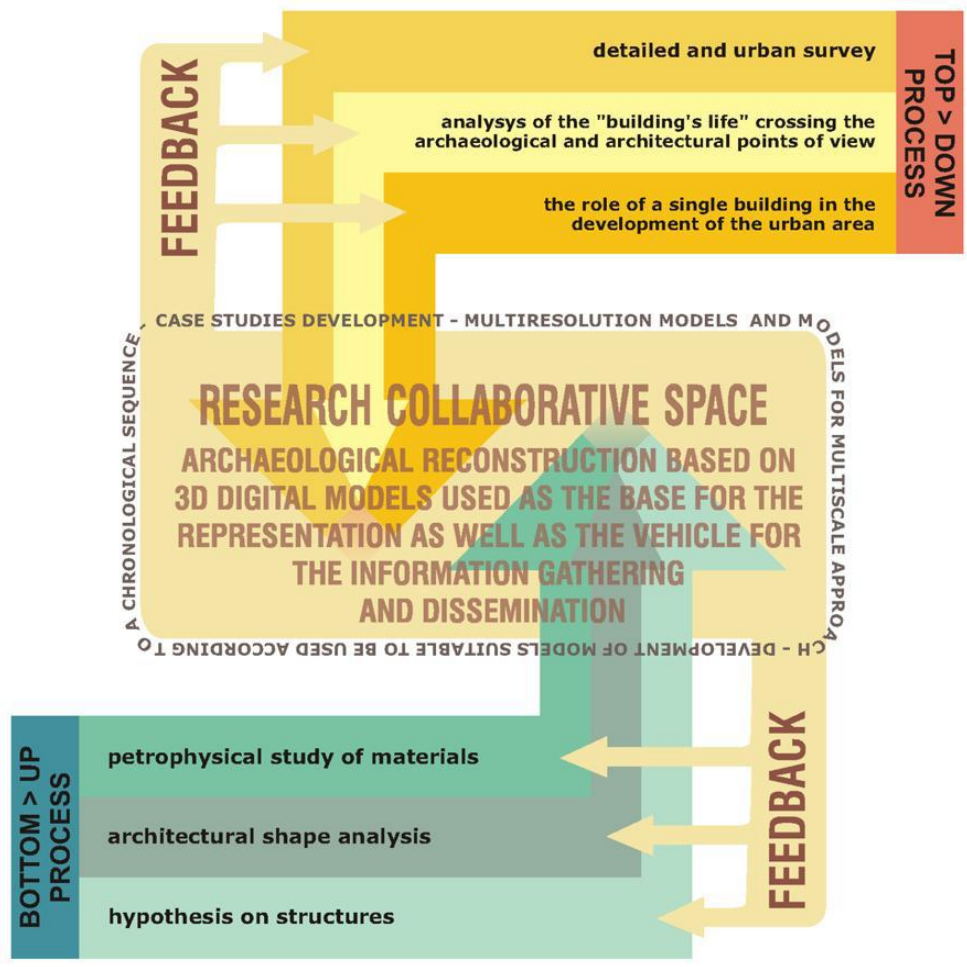

Fig. 9- The general workflow defined (from Columbu \& Verdiani, 2011)

The physical tests were determined on cubic specimens cut from fragments taken to monument. The volumes and solid, real and bulk densities of the rock specimens were determined with a helium Ultrapycnometer 1000 (Quantachrome Instruments), with water absorption tests by immersion and through a hydrostatic analytical balance.

Total porosity, open porosity to water and helium, closed porosity to water and helium, and weight imbibition coefficient were computed using the volumes and weights (dry, wet, hydrostatic-wet) of specimens. 
The punching strength was determined with a Point Load Tester (D550 Controls Instrument) according with the ISRM $(1972 ; 1985)$ on the same pseudo-cubic rock specimens used for other physical properties.

To proceed with the particle-size analysis of mortar aggregate, the samples were disaggregated and then attached with acid solution (HNO3, 13\% vol.), so as to eliminate the carbonate binder matrix. The particle-size distribution was performed using sieves series UNI 2131, with mesh opening of 4000, 2000, $500,250,125,63 \mu \mu$ with sifter Giuliani IG3.

The thermo-gravimetric analysis of the samples was conducted by means of thermal balance Perkin Elmer TGA 7 thermogravimetric analyzer, with a range of temperatures between $20^{\circ}$ and $890^{\circ} \mathrm{C}$, with a scanning rate of $10^{\circ} \mathrm{C} / \mathrm{min}$ (argon atmosphere). The differential scanning calorimetry is conducted with calorimeter Perkin Elmer DSC 7 in a range of temperatures between $20^{\circ}$ and $650^{\circ} \mathrm{C}$ with a scanning rate of $10^{\circ} \mathrm{C} / \mathrm{min}$.

\subsection{Archaeological approach}

The program of stratigraphic investigation has allowed to identify structural parts not currently visible and to recover elements of material culture, essential to provide a more accurate timing of this class monumental.

The excavations concerned the upper part of monument in cyclopean technique and the area southern immediately behind the structure.

Numerous shards of ceramic, lithic, plaster, animal bones, teeth, and fragments of charcoal were collected from the levels of which related to living spaces. From these materials were sampled all that lay in good conditions (in situ). All samples were recorded according to the Cartesian coordinates, and positioned within the drawing of the excavation plan. They were collected and placed in individual plastic box or bag. These materials were then kept at the Museum of Menorca while waiting to be sent to the different specialized laboratory for specific analysis.

\section{Discussion and conclusions}

The researches on the main monument of Cap de Forma have allowed to reconstruct although partially the events that have affected the structure and its long use over time, certainly determined by the high strategic potential of site.

The whole excavation area appeared involved by a thin layer of soil, very incoherent, beige colored yellowish-gray, which stays, in part directly on the slabs of the wall surface, in part on other flaps of deposit.

The accurate excavation has allowed to distinguish the deposit formed by wind action and following the collapse of the structures and, instead, that intentionally put in place together with an overlying layer of gravel, to stabilize the surface area in order to facilitate the inhabitation of the same for military purposes.

This arrangement was presumably made in not ancient times, in the same time of the installation of a fortified house.

Beyond that, on top of the monument has been carried out the check of the holes, presumably connected with military actions when the cape and the monument were exploited as a lookout.

The removal of the deposit disposed in part above the structure in cyclopean technique and in part on the front of it, allowed to highlight the presence of some living spaces leaning against the monument, implanted in talayotic period and, more precisely, into the final phases of the Bronze Age (XIII-XI century BC) (Depalmas, 2014).

Part of high interest, which is also the specific subject of this paper, therefore, is relative to the seventeenth century plant of the lookout and the changes operated in the prehistoric structures from the group allocated in the Cap.

In fact in this period had place the installation of the fort / lookout, the put in work of a lime production area (presumably burning the stones of the Talayotic cyclopic wall), enlargement (?) of the tank mouth and inside this the repair of cracks with lime, the fill the area occupied by prehistoric houses with a layer of gravel. 


\section{References}

Columbu S., Verdiani G. (2011). From the small elements to the urban scale: An investigation where petrophysical study of materials and architectural shape analysis try to read a masterplan in the Hadrian's Villa, Tivoli (Rome, Italy). Proceedings 16th Inter. Conference on Cultural Heritage and New Technologies, Urban Archaeology and Prospection, Museen der Stadt - Stadtarchäologie, Wien. 14-16 november 2011. eBook Ed., vol. 1, part 3, pp. 273-293, ISBN 978-3-200-02740-4

Columbu S., Gioncada, A., Lezzerini, M., Marchi, M. (2014), Hydric dilatation of ignimbritic stones used in the church of Santa Maria di Otti (Oschiri, northern Sardinia, Italy). Ital. J. Geosci. (Boll. Soc. Geol. It.), Vol. 133, 1, pp. 149-160.

Columbu S., Sitzia F., Verdiani G. (2015), Contribution of petrophysical analysis and 3D digital survey in the archaeometric investigations of the Emperor Hadrian's Baths (Tivoli, Italy). Rendiconti Lincei, Springer (in press).

Coroneo R., Columbu S. (2010), Sant'Antioco di Bisarcio (Ozieri): la cattedrale romanica e i materiali costruttivi. Archeoarte, vol. 1, p. 145-173, ISSN: 2039-4543, doi: DOI: 10.4429/j.arart.2010.01.10

Depalmas A. (2014), New data from fortified coastal settlement of Cap de Forma, Mahon, Menorca (Balearic Islands). Radiocarbon, Vol. 56, N. 2. pp. 425 - 437.

Folk R.L. (1959), Practical petrographic classification of limestones. American Association of Petroleum Geologists Bulletin. pp. 1-38.

Folk R.L. (1965), Petrology of Sedimentary Rocks, Hemphill.

International Society for Rock Mechanics (1972). Suggest method for determining the point load strength index. ISRM (Lisbon, Portugal). Committee on Field Tests; 1: pp. 8-12.

International Society for Rock Mechanics (1985), Suggest Method for determining the point load strength index ISRM. Commission for Testing Methods, Working Group on Revision of the Point Load Test Methods. Int. J. Rock Mech. Min. Sci. and Geomech.; 33: pp. 51-60.

Martínez Santa-Olalla J. (1935), Elementos para el estudio de la cultura de los talayots en Menorca. Actas y Memorias de la Sociedad Española de Antrop., Etnografia y Prehistoria 14 (1). pp. 5-66.

Mascaro Pasarius J. (1968). Prehistoria de las Balears. Pasarius Ed. Palma de Mallorca.

Moropoulou A., Polikreti K., Bakolas A., Michailidis P. (2003), Correlation of physicochemical and mechanical properties oh historical mortars and classification by multivariate statistics, Cement and concrete research 33, pp. 891-898.

Recommendations Nor. Ma. L. $3 / 80$ (1980), Stone materials: Sampling (Reprint 1988).

Recommendations Nor. Ma. L. 1/88 (1988), Macroscopic alterations of stone materials.

Plantalamor Massanet Ll. (1991a), Los asentamientos costeros en la isla de Menorca. Atti del II congresso Internazionale di Studi Fenici e Punici (Rome, 9-14, November 1987) III. Consiglio Nazionale delle Ricerche Ed Roma. pp. 1151-1160.

Plantalamor Massanet Ll. (1991b), L'arquitectura prehistòrica i protohistòrica de Menorca i el seu marc cultural. Treballs del Museu de Menorca 12. Conselleria de Cultura, Educació i Esports Ed. Mahon.

Plantalamor Massanet Ll., Tanda G., Tore G., Baldaccini P., Del Vais C., Depalmas A., Marras G., Mameli P., Mulé P., Oggiano G., Spano M. (1999), Cap de Forma (Minorca): la navigazione nel Mediterraneo occidentale dall'età del bronzo all'età del ferro. Nota preliminare. Antichità Sarde. Studi e Ricerche 5. Stamperia Artistica Ed. Sassari. pp. 11-160.

UNI EN 1936 (2001), Natural stone test methods - Determination of real density and apparent density and of total and open porosity.

UNI EN 13755 (2002), Natural stone test methods - Determination of water absorption at atmospheric pressure. 